\title{
PLANT FINDS IN SASKATCHEWAN, 1980 AND 1981
}

JOHN H. HUDSON, 323 Maple St., Saskatoon, Saskatchewan. S7J OA6

Despite the title, I found no plant records really worth writing about in 1980. However, 1981 was more fruitful. This season was highlighted for me by the discovery of Sand Puffs or Sand Verbena (Abronia micrantha (Hook) Torr.) just within the limits of Saskatchewan.

Hope Johnston gave us in 1975 the story of her rediscovery of this plant on loose sand in the valley of the South Saskatchewan River, some $15 \mathrm{mi}$ downstream from Medicine Hat. ${ }^{3} \mathrm{~A}$ lifelike drawing was given therein, so that I need give little description of Sand Puffs other than to say that the fruiting plant looks like Sand Dock (Rumex venosus) but it is an annual with opposite leaves. Reading the description of its habitat in the Johnston article set me thinking how one would go about finding Sand Puffs in Saskatchewan. Evidently it requires loose sand under conditions as hot as possible, so one should look:

(1) As high up the South Saskatchewan River as possible, to be nearest the known Alberta stations; (2) in generally sandy country; (3) deep down in the valley to find a hot

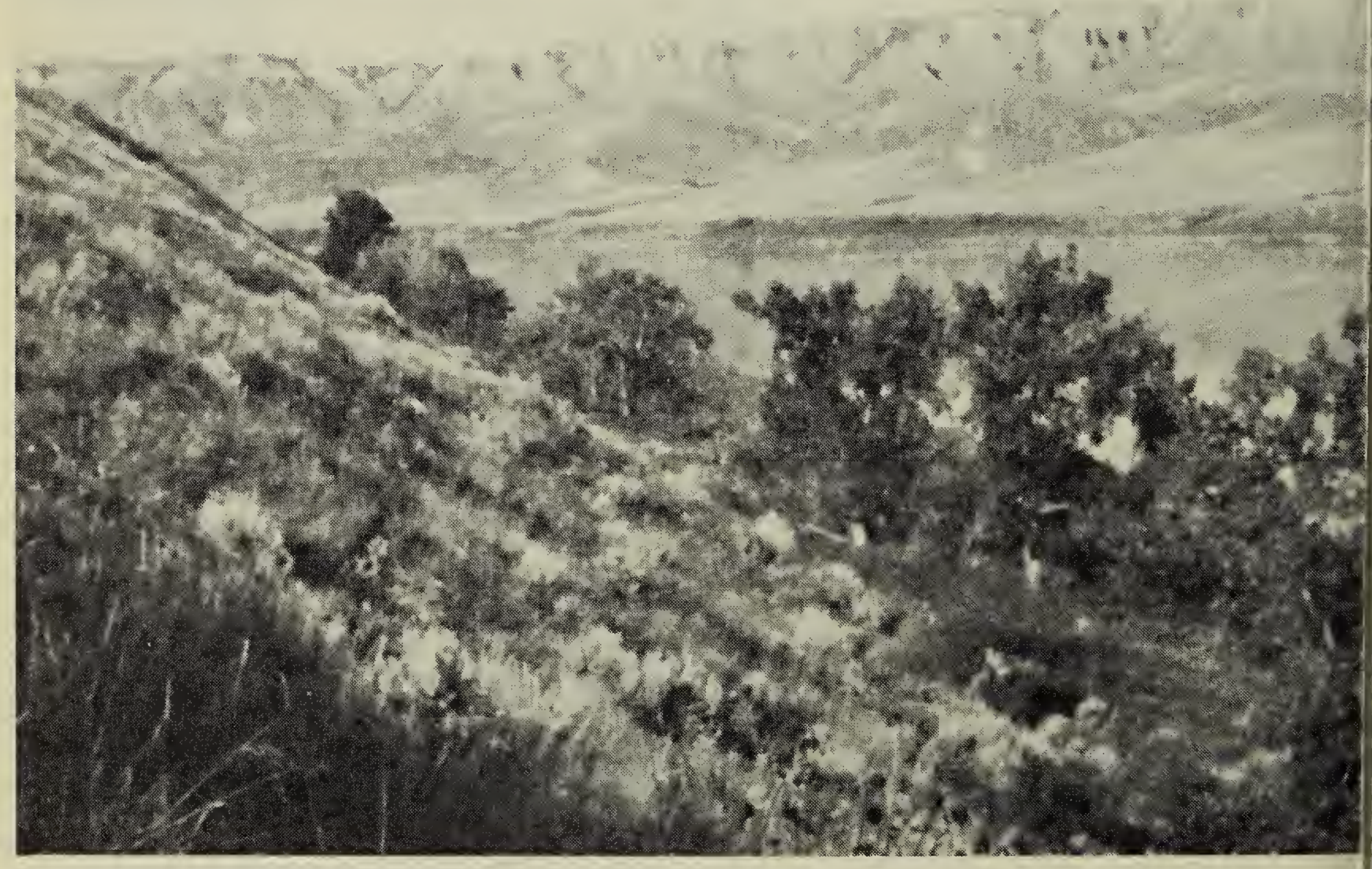

South Saskatchewan River looking north, around the curve of the hill from the Sand Puffs site.

John Hudso: 
microclimate; (4) on the inner or convex side of a bend of the river, and therefore on the slip-off slope where the soil would be alluvially deposited sand.

These requirements are met by a little bit of Saskatchewan s. of Empress, Alberta in sections 5, 6, 7 and 8 in 22$29-\mathrm{W}$ 3rd, where the South Saskatchewan River bends into Saskatchewan and out again before returning to Saskatchewan to join the Red Deer River.

Study of maps followed by a preliminary scouting on 21 June showed that the nearest one could get to this tract of land by car was a point $1.5 \mathrm{mi}$ east of Alberta Highway No. 41, $3.5 \mathrm{mi}$ from the Saskatchewan boundary. So on 11 July I drove there, loaded a shoulder bag with lunch, a map, and assorted tins of juice, and set out to walk the distance, some $5 \mathrm{mi}$ out and $5 \mathrm{mi}$ back. The country was trackless sandy prairie; one could estimate where one was only from one's watch and an assumed speed of $3 \mathrm{mph}$. Except for aircraft overhead, the landscape was just as it was before settlement - it wasn't even overgrazed. An antelope inspected me from a viewpoint atop a sandhill.

When I arrived at the river breaks, a eer was drinking from the river in broad aylight. A search of the loose sandy lopes soon turned up Sand Puffs at a oint about 70 feet above the water. It as a little surprising how soon I found it fter arriving at a theoretically suitable lace. I also noted with interest how ripe e plants were by 11 July, but recalled lat Johnston had described its life ycle as that of a desert ephemeral. he 3-winged fruits are a trifle smaller nd less red than those of Sand Dock, ut are wholly similar in form. The fruits the two species are plainly evolved in arallel for dispersal by rolling before e gusty winds of sand dunes.

got back to the car at sunset conventionally tired but happy. More exactly, I was used up, with intervertebral disks flattened so that a step down the slightest drop jolted all along the spine, but with a coating of that selfsatisfaction which comes from accomplishing what one set out to do and seeing one's theories working out in fact.

Collection data are: Abronia micrantha (Hook) Torr., Hudson 4152 , 11 July 1981, L.S.D. 11 in 5-22-29 W 3rd, steep sloping cutbank of loose sand.

Some other records from the hot inner valley of the South Saskatchewan River in the Empress area (Saskatchewan side) may also be given. Least Cryptanthe (Cryptantha minima Rydb). Hudson 4151, 21 June 1981, Empress, L.S.D. 1 in 9-23-29 W 3rd, dry sandy south facing slope in ravine. This small Crypthanthe had been collected by myself (Harms \& Hudson 1978) from the yard of an abandoned elevator at Westerham. No. 4151 is from a more natural, though unstable, habitat.

Stinking Goosefoot (Chenopodium dacoticum Standley). Hudson 4149, 21 June 1981, Empress, L.S.D. 1 in 9-23$29 \mathrm{~W}$ 3rd, arid silty soil on valley bottom; Hudson 4159, 12 July 1981, Empress, L.S.D. 16 in 4-23-29 W 3rd, arid silty bench in ravine. This small goosefoot with white-mealy more or less circular leaves may be separated from all other Chenopodia (goosefoots) by its odor of dead fish, caused by amines, which may be perceived even in dried material. It is found in Saskatchewan only in hot microclimates within the inner valleys of the South Saskatchewan and Frenchman rivers. It has gone under the alternate name of $C$. watsonii $A$. Nels. but Maher et al seem to have finally settled on C. dacoticum. ${ }^{4}$ They report it from Ravenscrag, Lancer Ferry, and Kyle.

These three species of desert or at least hot arid conditions are at the northeast edge of their ranges and thus are 
found only in the sheltered lower benches of deep valleys where the requisite hot summer microclimates exist. Particularly for Stinking Goosefoot was it possible to observe that it couldn't be found at all on the high ground at prairie level, even on suitably dry soil. Nodding Umbrella Plant (Eriogonum cernuum) recorded by Maher et al for Lancer Ferry and Webb - also collected by me on these Empress forays as No. 4150 and No. 4154 - has similar habitat needs. ${ }^{4}$

One more record of interest for Saskatchewan, is the finding of a second station for Hairy Prairie Clover (Petalostemon villosum Nutt.), southwest of Dundurn. Breitung reported it as new to Saskatchewan 23 years ago, based on a collection of mine from the Caron area. ${ }^{1}$ Details of the Dundurn collections run thus: Hudson 4165, 17 July 1981, Dundurn, about L.S.D. 15 in 10-32-6 W 3rd, loose sand east side of sand dune; Hudson 4178, 14 August 1981, Proctor Lake, about L.S.D. 8 in 7-32-5 W 3rd, semistabilized blowout. It seems to be confined to at least semi-moving sand blowouts. Some years earlier I had seen in the Fraser Herbarium, University of Saskatchewan, an unmounted student collection of this Hairy Prairie Clover marked only "Dundurn" for locality, so I knew there was some likelihood of locating colonies of this attractive plant if one made enough forays into the Dundurn Sandhills.

Duplicates of these collections have been deposited with the herbaria SASK. (University of Saskatchewan), REG. (University of Regina), QFA (University of Laval).

BREITUNG, A.J. 1959. Supplement to "Flora of Saskatchewan". Am. Midland Naturalist 61 (2), 510-512.

${ }^{2}$ HARMS, V.L., and HUDSON, J.H. 1978. Some Vascular Plants New to the Flora of Saskatchewan. Canadian FieldNaturalist 92, 389-391.

3JOHNSTON, HOPE and HALLWORTH BERYL. 1975. Further Discoveries o: Sand Verbena in Alberta. Blue Jay 33 (1), 13-15.

${ }^{4}$ MAHER, R.V., ARGUS, G.W., HARMS V.L., and HUDSON, J.H. 1979. The Rare Plants of Saskatchewan Syllogeus No. 20, National Museum o Canada, Ottawa.

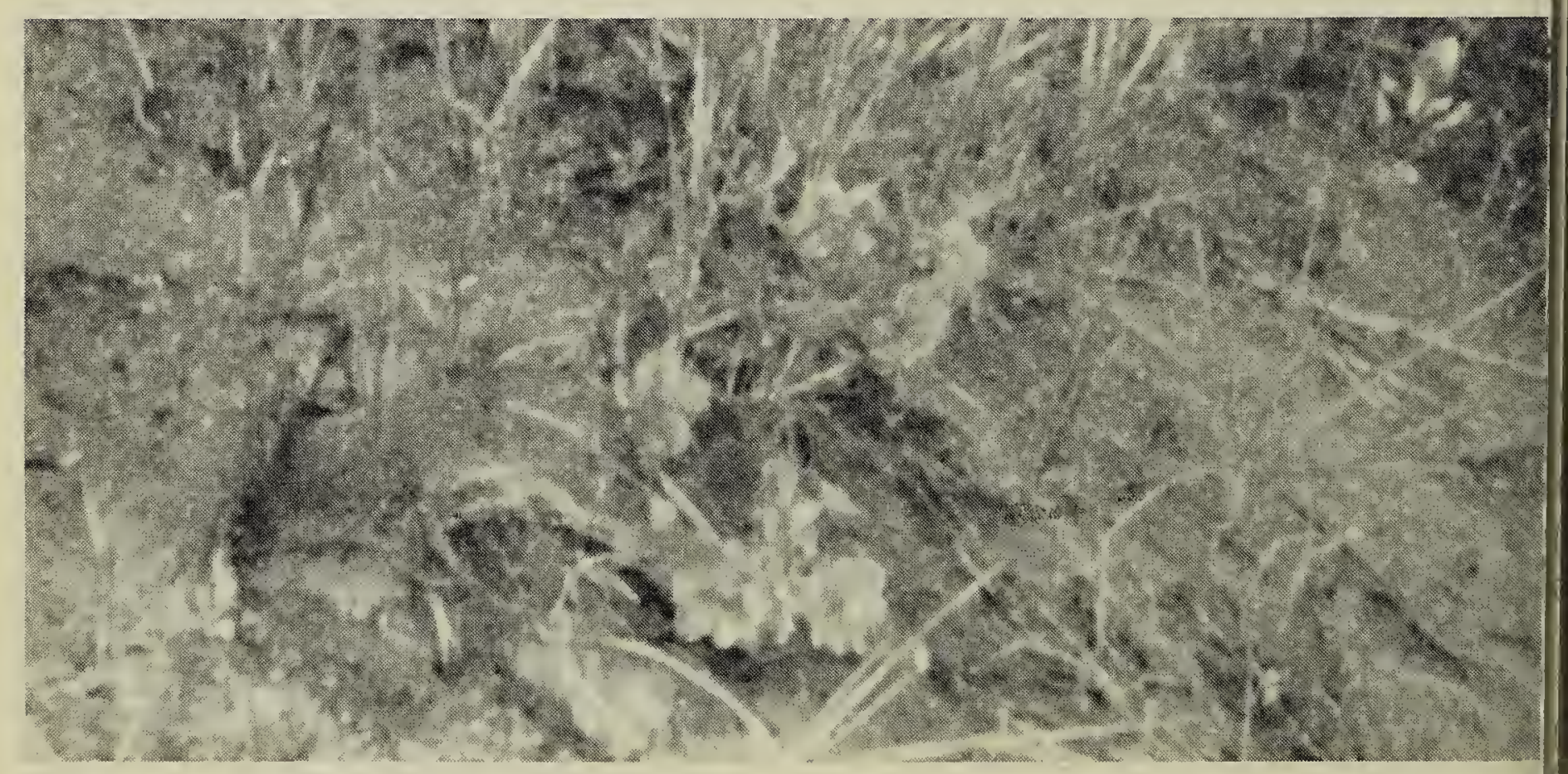

